\title{
一次元河川生態系モデルの開発と 佐波川への適用 \\ MODELLING AND APPLICATION OF ONE-DIMENSIONAL RIVER ECOLOGICAL MODEL IN SABA RIVER
}

\author{
赤松良久 $1 \cdot$ 上鶴翔悟 $2 \cdot$ 高村紀彰 $3 \cdot$ 永野博之 4 \\ Yoshihisa AKAMATSU, Shogo KAMITSURU, Yoshiaki TAKAMURA and Hiroyuki NAGANO \\ 1正会員 博 (工) 山口大学大学院准教授 理工学研究科社会建設工学専攻 \\ （テ755-8611 山口県宇部市常盤台2-16-1） \\ 2学生会員 修(工) 山口大学大学院生 理工学研究科社会建設工学専攻 \\ （テ755-8611 山口県宇部市常盤台2-16-1） \\ 3非会員＼cjkstart修(工）（株）中電技術コンサルタント（干734-8510 広島市南区出汐二丁目3番30号） \\ 4 正会員 博(工) （株）八千代エンジニヤリング 名古屋支店（一460-0003 愛知県名古屋市中区錦3-10-33）
}

In the river assessment, it is necessary to discuss the mass balance in the river ecosystem using river ecological model. A new model of river ecosystem consists of one-dimensional unsteady flow, onedimensional calculation of bed variation, heat balance, water quality and biological model. This model was applied to Saba River, where water quality and biological environments have been observed at four points in the river basin in two month intervals. The temporal variations of water level, water temperature, dissolved oxygen and amount of attached algae obtained from this model show a good agreement with the observed results, indicating that this model is valid for simulating the mass balance in the river ecosystem.

Key Words : ecological model, river ecosystem, assessment method, Saba River

\section{1. はじめに}

水環境に関する現象理解のための物質収支に着目した 研究は1914年頃から始まった。 その後，コンピューター の性能の向上とともに生物や各種物質を考慮した物質収 支モデルが開発され，閉鎖性の湖沼や内湾を対象として 物質収支モデルをべースとした様々な生態系モデルが開 発されてきた ${ }^{1)}$. しかし，開放性が強く，地形が大きく 変化する河川においての物質収支モデルの開発は十分に 進んでいない.

近年では, 河川の各区間の特徵的な物質循環を考慮し たモデルが開発されている．例えば，戸田ら²は碩床河 川において生物の一次生産に着目した物質循環を明らか にしている. また，赤松ら ${ }^{3}$ は河川感潮域のマングロー ブ水域において地下浸透流も考慮した物質循環モデルに よって, 溶存態栄養塩の輸送特性を明らかにしている.

しかし，これらのモデルは対象域の物質循環の特徵を詳 細に評価可能であるというメリットはあるものの，開放 性が高く上下流との連続性が重要となる河川においては 境界域での詳細な現地調査が必要不可欠である. 溝口ら
${ }^{4)}$ は粗粒状有機物のサイズ変化・分解・輸送過程を考慮 した水系一貫物質循環モデルを構築し，流量・川幅が単 純に増加するモデル河川に適用している，また，そのモ デルを実河川流域に適用しているものの，実測データと の比較は十分に行われていない ${ }^{5}$. さらに，河川の物質 循環と同時に，河床変動を考慮可能な生態系モデルの構 築は行われていない.

そこで, 本研究では物質循環・河床変動を考慮し，河 川水系について上流域から下流域まで一貫して取り扱う ことができる一次元河川生態系モデルの開発を行うと共 に, 実河川への適用として山口県の一級河川である佐波 川を対象に，数值解析を行うことを目的とする.

\section{2. 河川生態系モデル}

\section{（1）モデルの概要}

本研究で使用する一次元河川生態系モデルは，(a)河川 の流れ場を解析寸る一次元不定流モデル，(b)水温を解析 する熱収支モデル，(c)水質を解析する物質輸送モデル， 


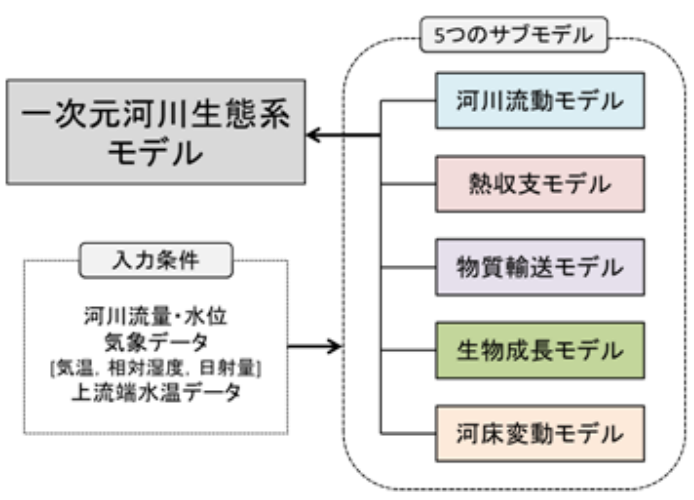

図-1＼cjkstart河川生態系モデルの概要図

(d)生物バイオマスを解析寸る生物成長モデル，(e)河床形 状を解析する河床変動モデル，の5つのサブモデルによ り構成されている（図-1）。なお，断面形状は一般断面 で計算を行い, 各生物・物質量は流水断面平均值である. 物質輸送モデルで扱う物質として, 粒子態有機炭素 $P O C$, 溶存態有機炭素 $D O C$, アンモニア態窒素濃度 $N H_{4}-N$, 亜 硝酸態窒素濃度 $N O_{2}-\mathrm{N}$, 硝酸態窒素濃度 $N O_{3}-\mathrm{N}$, リン酸 態リン濃度 $\mathrm{PO}_{4}-\mathrm{P}$, 溶存酸素濃度 $D O$ を扱い, 堆積物とし て粒子態有機物堆積量 $S e_{A}$ を扱う. 生物成長モデルでは, 付着藻類, 植物プランクトン, 動物プランクトン, 底生 動物，魚類を扱う。これらの生物と物質を考慮した河川 生態系における物質循環を図-2に示寸。

\section{(2) 河川流動モデル}

流れ場の解析には以下の2式を用いた。

$$
\begin{gathered}
\frac{\partial A}{\partial t}+\frac{\partial Q}{\partial x}=0 \\
\frac{\partial Q}{\partial t}+\frac{\partial}{\partial x}\left(\frac{Q^{2}}{A}\right)=-g A \frac{\partial z}{\partial x}-\frac{\partial}{\partial x}\left(\frac{g}{2} A h\right)-g A I_{e}
\end{gathered}
$$

ここに, $A:$ 流水断面積 $\left[\mathrm{m}^{2}\right], Q:$ 流量 $\left[\mathrm{m}^{3} / \mathrm{s}\right], z:$ 河床高 $\left[\mathrm{m}^{2}\right], g:$ 重力加速度 $\left[\mathrm{m} / \mathrm{s}^{2}\right], h:$ 水深 $[\mathrm{m}], I_{e}:$ エネルギー 勾配である.

\section{（3）熱収支モデル}

水温 $T_{W S}\left[{ }^{\circ} \mathrm{C}\right]$ は, 式(3)に示寸一次元移流拡散方程式に より求めた.

$$
\begin{aligned}
& \frac{\partial B h T_{W}}{\partial t}+\frac{\partial B h u T_{W}}{\partial x}=\frac{\partial}{\partial x}\left(B h D_{x} \frac{\partial T_{W}}{\partial x}\right)+B \frac{T E}{c_{w} \rho_{w}} \\
& +q_{S}\left(T_{W S}-T_{W}\right) \\
& D_{x}=(0.01 B)^{\frac{4}{3}} \\
& T E=\text { Rnet }-l E-H_{T}-G
\end{aligned}
$$

ここで, $B: 川$ 幅 $[\mathrm{m}], h$ : 水深 $[\mathrm{m}], T_{\mathrm{WS}}$ : 横流入水の水 温 $\left[{ }^{\circ} \mathrm{C}\right], D_{x}$ : 分散係数 $\left[\mathrm{m}^{2} / \mathrm{s}\right], c_{w} \rho_{w}$ : 水の熱容量 $\left[\mathrm{J} / \mathrm{K} / \mathrm{m}^{3}\right]$ と

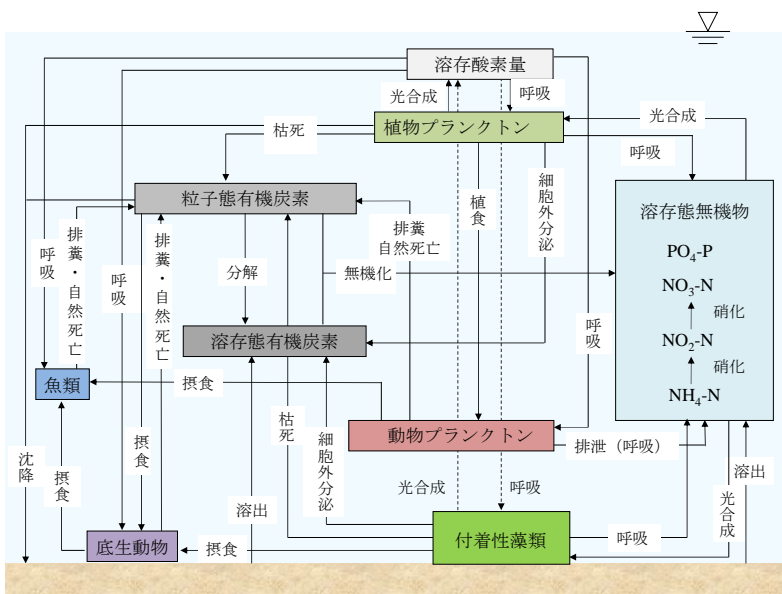

図-2 河川生態系における物質循環

する. TEは単位面積当たりの水面及び河床でのエネル ギーフラックス $\left[\mathrm{W} / \mathrm{m}^{2}\right]$ であり，大気と接触する水面にお いて水柱へと供給される正味のエネルギーである正味放 射量Rnet $\left[\mathrm{W} / \mathrm{m}^{2}\right]$, 水表面からの蒸散の際に奪われる潜熱 量 $l E\left[\mathrm{~W} / \mathrm{m}^{2}\right]$, 大気を加熱する際に使われる顕熱量 $H_{T}\left[\mathrm{~W} / \mathrm{m}^{2}\right]$, 河床面において河川水から河床一伝わる河床 伝熱量 $G\left[\mathrm{~W} / \mathrm{m}^{2}\right]$ の合計である。

\section{(4) 物質輸送モデル}

各物質 $\left(P O C, D O C, N H_{4}-N, N O_{2}-N, N O_{3}-N, P O_{4}-P\right.$, $D O ）$ および動植物プランクトンに関しては以下の移流 拡散方程式で表される.

$$
\frac{\partial C}{\partial t}+u \frac{\partial C}{\partial x}=\frac{\partial}{\partial x}\left(D i s \frac{\partial C}{\partial x}\right)+C *
$$

ここに, $C$ : 水深平均物質濃度, Dis:物質拡散係数であ る. また, 右辺第二項は移流, 拡散を除く生成・消滅項 を表す，各物質に関する生成・消滅項の詳細 $\left.{ }^{3}, 5\right)$ は割愛す る.

\section{(5) 生物成長モデル}

a) 付着性藻類

付着性藻類の現存量 $A\left[\mathrm{~g} / \mathrm{m}^{2}\right]$ は次式で表される.

$$
\frac{d A}{d t}=G_{A}-P A-k_{a e} A-G_{S R}
$$

ここに, $P$ : 藻類の剥離による減少率 $\left[\mathrm{s}^{-1}\right], k_{a e}$ : 代謝速度 $\left[\mathrm{s}^{-1}\right], G_{S R}$ : 底生動物の成長による増加量 $\left[\mathrm{g} / \mathrm{m}^{2} / \mathrm{s}\right]$ である. 右辺第1項は光合成による増殖，第2項は剥離による減少， 第3項は代謝・分解に伴う減少，第4項は底生動物の摂食 による減少を表している，なお，藻類の剥離による減少 率 $P$ は赤松らొを参考に算出寸る。 ここで，減少率 $P$ は河 床変動モデルで計算される掃流砂量の関数である.

\section{b）底生動物}

底生動物のモデル化については，今村ら ${ }^{8)}$ を参考とし て行った. 底生動物の現存量 $B_{S R}\left[\mathrm{~g} / \mathrm{m}^{2}\right]$ は次式で表される.

$$
\begin{aligned}
\frac{\partial\left(B_{S R}\right)}{\partial t} & =G_{S R}+\left(1-e_{S R}\right) G_{S R}-\left(e_{S R}-g_{S R}\right) G_{S R} \\
& -D_{S R} B_{S R}-E_{S R} B_{S R}
\end{aligned}
$$


ここで, $e_{S R}$ : 底生動物の同化効率[-], $g_{S R}$ : 底生動物の総 成長率[-], $D_{S R}$ : 自然死亡速度 $\left[\mathrm{s}^{-1}\right], E_{S R}$ : 羽化速度 $\left[\mathrm{s}^{-1}\right]$ で ある. 右辺第 1 項 $G_{S R}$ は摂食による増殖，第2項は排糞， 第3項は排泄による減少, 第4項は自然死亡による減少, 第5項は羽化による減少である.

\section{(c) 魚類}

魚類については, 李ら ${ }^{9)}$ を参考に浮魚, 底魚を分類し, モデル化を行った．それぞれの現存量 $\left.W \mathrm{~g} / \mathrm{m}^{2}\right]$ は以下の ように表される.

$$
\frac{\partial W}{\partial t}=E-F-U-R-D
$$

ここで, $E:$ 摂餌量 $\left[\mathrm{g} / \mathrm{m}^{2} / \mathrm{s}\right], F:$ 排粪量 $\left[\mathrm{g} / \mathrm{m}^{2} / \mathrm{s}\right], U:$ 分泌 量 $\left[\mathrm{g} / \mathrm{m}^{2} / \mathrm{s}\right], R:$ 呼吸量 $\left[\mathrm{g} / \mathrm{m}^{2} / \mathrm{s}\right], D:$ 死亡量 $\left[\mathrm{g} / \mathrm{m}^{2} / \mathrm{s}\right]$ を表し ている.

\section{(6) 河床変動モデル}

全流砂の連続式は全ての粒径の流砂の交換を考慮し次 式で表される.

$$
\frac{\partial \eta}{\partial t}+\frac{1}{1-\lambda}\left[\frac{1}{B} \times \frac{\partial \sum_{i}\left(q_{B i} B\right)}{\partial x}+\sum_{i}\left(q_{s u i}-w_{f i} c_{b i}\right)\right]=0
$$

ここに, $\lambda$ : 河床材料の空隙率, $\eta$ : 平均河床高 $[\mathrm{m}], w_{f i}$ : 粒径別浮遊砂の沈降速度 $[\mathrm{m} / \mathrm{s}], c_{b i}$ : 河床付近の粒径別浮 遊砂濃度 $\left[\mathrm{g} / \mathrm{m}^{3}\right]$ と寸る. また, $q_{B i}$ : 粒径別単位幅掃流砂量 $\left[\mathrm{g} / \mathrm{m}^{2}\right], q_{s u t}:$ 粒径別浮遊砂の単位面積当たりの河床からの 浮上量 $\left[\mathrm{g} / \mathrm{m}^{2}\right]$ にいてはそれぞれ粒径別の芦田・道上の 式 ${ }^{10)}$ ，Itakura and Kishiの式 ${ }^{11)}$ 用いた.

\section{3. 佐波川への適用}

\section{(1) 対象河川の概要と現地調査}

佐波川は山口県のほぼ中央に位置する幹川流路延長 $56 \mathrm{~km}$ ，流域面積 $460 \mathrm{~km}^{2}$ の一級河川である，佐波川流域 図と計算対象とする区間を図-3に示す，対象とする区域 は4k400～23k200とし，さらに堰による影響を考慮する ため，区間1～3 と分割する． 区間1は島地川合流後の漆 尾観測所を上流端とし，下流端を上右田堰直上とする. 区間 2 は，上右田堰の直下から，防府総合堰直上間とす る。また，区間3は，防府総合堰直下から佐野堰直上間 とし計算区間を設定した。

また，数值解析に先立ち，対象区間内において現地調 査を行った. 図-4に示寸計算区間において，区間1の上 流端にあたる漆尾地点と新橋地点に水温計を2013/1/1 2013/10/22にわたり設置した．さらに，区間3の新橋地点 において，日射計による計測を2013/5/13〜2014/1/9，DO 計による計測を2013/10/4〜2014/1/9に行った。 また，各

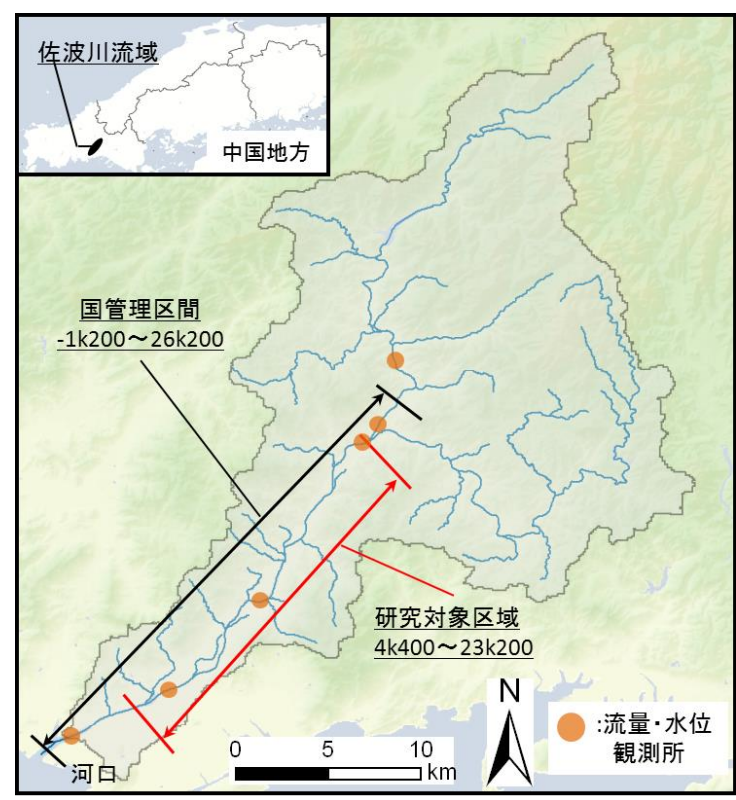

図-3 佐波川流域の概要

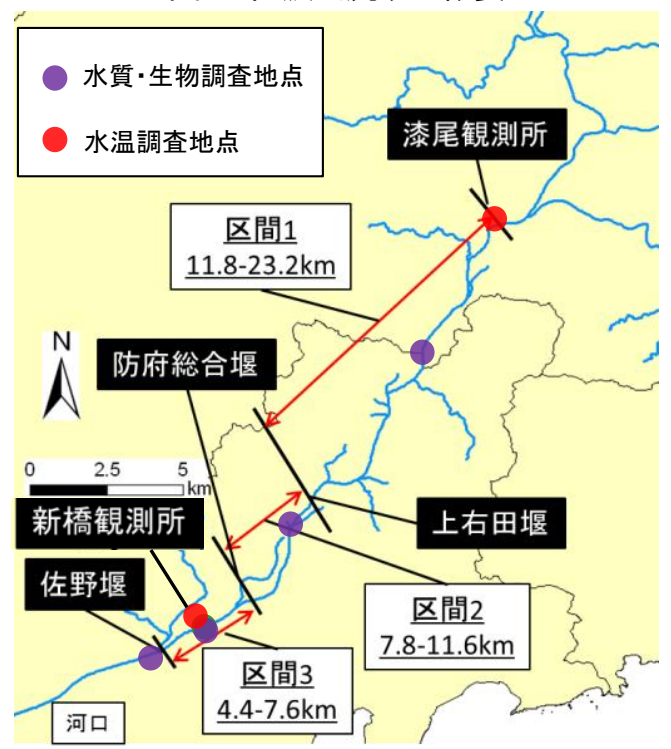

図-4 佐波川流域の観測地点

計算区間の下流端に当たる堰の直上に水位計を設置し 2013/9/15〜2014/1/9にわたり計測した。また，2013/8/22， 8/23において計算区間内から堰の直上直下を中心に 45 地 点にわたり，水サンプルの採取を行い，栄養塩濃度の分 析を行った，さらに，2013/3/11, 6/16,8/19, 10/23, 12/27に 図-4に示寸4地点において，水質（DO, T-N, $\mathrm{NO}_{3}-\mathrm{N}, \mathrm{NH}_{4}$ $\left.\mathrm{N}, \mathrm{NO}_{2}-\mathrm{N}, \mathrm{T}-\mathrm{P}, \mathrm{PO}_{4}-\mathrm{P}\right)$ ，魚類，底生動物，付着藻類のサ ンプリングを行った. 魚類に関しては単位面積当たりの 湿潤重量を，底生動物および付着藻類に関しては乾燥重 量を計測した.

\section{（2）モデルの再現性の検証}


本モデルの検証計算は，まず流れ場の再現性の検討と して計算水位と実測水位の比較・検討を行った後, 水温, 付着藻類量, 溶存酸素濃度の再現性についての検討を 行った.

\section{a) 流れ場の再現性の検討}

流孔場の再現性の検討は，1400[ $\left.\mathrm{m}^{3} / \mathrm{s}\right]$ を超える出水を 記録した2009/7/19 10:00〜7/22 9:00を計算対象期間とし

（図-5），区間3において，計算より得た水位と国土交 通省より提供されている新橋観測所の実測水位との比較 を行った，上流端流量は，新橋観測所の実測值を与え， 下流端は等流水深とした．また，マニングの粗度係数に ついては，0.035を与えた。

図-6に新橋観測所における水位の実測值と計算值の比 較を示寸，水位の時間的な変動については実測值と計算 值は概ね一致していることが分かる．流量のピーク時で ある2009/7/21 14:00において新橋観測所の実測値は 7.06[m]であるのに対して，同時刻の計算值は7.15[m]で あることから，流れ場については十分な再現性があると 言える.

\section{b) 水温 · 付着藻類量の再現性の検討}

熱収支・付着藻類モデルの再現性の検討については, 2013/6/1 1:00〜 7/1 0:00の一ヶ月間を対象期間として行っ た．選定理由としては，2013/5/29に $150\left[\mathrm{~m}^{3} / \mathrm{s}\right]$ 程度の出水 があり，6/20に再び $300\left[\mathrm{~m}^{3} / \mathrm{s}\right]$ を超える出水が存在するた め, 付着藻類の出水後からの成長の過程を評価しやすい ためである．境界条件として，各区間の上流端へ観測所 の実測流量を与え，下流端は等流水深とした．各観測所 における流量を図-7に示寸。また，熱収支モデルの解析 に用いる気象条件として，日射量については新橋地点に 設置した日射計のデータを用い，気圧・気温データにつ いては気象庁より提供された山口観測所の值を一様に与 えている. 上流端の水温データについては設置した水温 計の実測值を与えることとする．付着藻類量の初期值に ついては出水による剥離後と考え，一様に $0.001\left[\mathrm{~g} / \mathrm{m}^{2}\right]$ を 与えて解析を行った。

新橋地点に設置した水温計の観測值と計算值の比較を 図-8に示す．また，赤の実線で上流端へ与えた観測值の 水温を表している. 水温は流下に伴い日射の影響等によ り上昇寸る傾向にあり，観測值，計算値ともに上流端值 より上昇していることが分かる．また，水温の日変化の 傾向について観測值と計算值を比較すると，計算值の方 が若干過大評価になる時期が存在するが比較的よく一致 している.このことから，本モデルで用いた熱収支モデ ルの再現性は高いと考えられる.

図-9に新橋地点における付着藻類量の計算結果と, 2013/6/16 11:00時点における観測による実測值を示寸. 計算值は，計算開始から徐々に増加を始め，6/18 16:00に おいて最大值 $9.4\left[\mathrm{~g} / \mathrm{m}^{2}\right]$ をとり，飽和状態になることがわ かる. しかし，流量の増加した6/19 12:00において掃流力

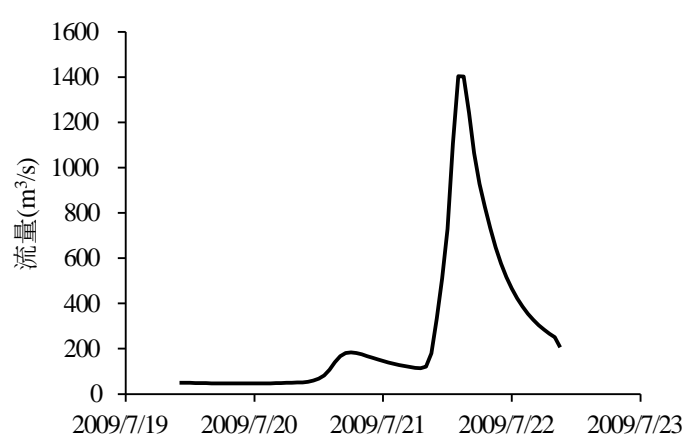

図-5＼cjkstart流れ場の検討に用いた新橋観測所流量

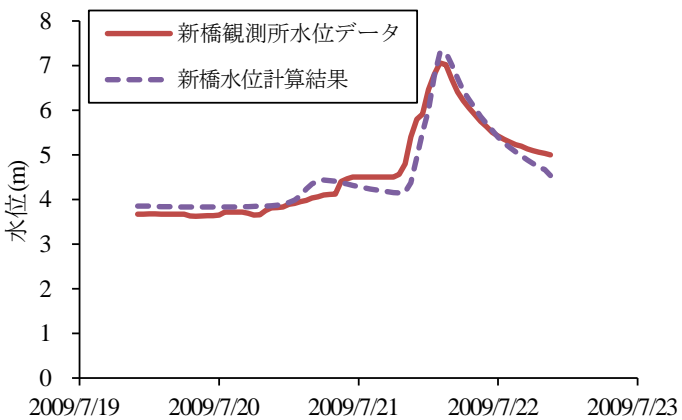

図-6＼cjkstart新橋観測所における水位の実測値と 計算値の比較

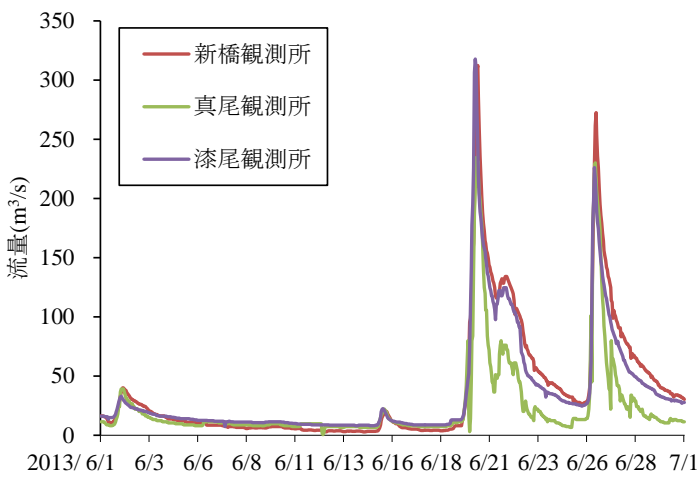

図-7 水温 ·付着藻類量の再現性の検討に用いた 各観測所流量

の増大から藻類の剥離が起こり，急激にゼロへと漸近す る. その後, 増加を始めるものの，再び $250\left[\mathrm{~m}^{3} / \mathrm{s}\right]$ を超え る出水によりゼロへ近づくという動向を示している．ま た，観測による実測值と計算值をみると，付着藻類量に 関しては少し過大評価となることが分かる.

\section{c）溶存酸素濃度の再現性の検討}

溶存酸素濃度の再現性の検討は，2013/10/12０:00～ 10/13 0:00における日変動を対象として行った. ここでは, 区間3に位置する新橋地点に設置したDO計の実測值と解 析值の比較を行うこととし，流量は新橋観測所の実測流 量を与え，下流端は等流水深とした.

図-10に新橋地点における溶存酸素濃度の計算結果と DO計による実測值を示す．溶存酸素濃度の日変動は日 
中に付着藻類の光合成による影響を受けて上昇し，日射 がなくなる夜間には生物項の呼吸による消費や，有機物 の分解等の作用により值が小さくなることが知られてい る. 観測值，計算值共に，日射量がピークになる午後 12:00前後で溶存酸素量は, 最大值をとっており, その後 減少していくという変化を見ることができる，このよう に，本モデルの溶存酸素濃度の解析は実河川においても 適用可能な再現性を持つことが分かった.

\section{(3)物質 · 生物量の長期時系列変化および縰断変化}

本生態系モデルの長期間における時系列及び縦断変化 を見るため，2013/9/16 1:00～2013/10/24 0:00の期間にお いて数值解析を行った. 流量は真尾観測所を除く, 各観 測所の実測流量を与えた。計算に用いた流量を図-11に 示寸，その他気象データ等の境界条件については，実測 データを与えることとする.

図-12に長期計算における新橋地点での溶存酸素度, 水温, 付着藻類量の計算結果を示す. 溶存酸素濃度の実 測值については計測開始日の2013/10/5以下のデータを示 している. また, 水温は同条件における計算值を表して いる. 付着藻類量については本条件下において計算開始 から1週間程度で飽和状態となりそれ以降頭打ちの状態 で推移していくことが分かる．溶存酸素濃度は河川水の 水温の影響を受け，水温が高いとベースラインは下がり， 水温が低くなるとベースラインは高くなるという傾向が 計算値，実測值共に現れている.

図-13に $\mathrm{PO}_{4}-\mathrm{P}$ の縦断変化の観測值と計算值の比較を示 す. 計算值については区間 1 の流端へ観測值を与えて いる. 流下にともなう縦断変化はほぼ見られず, $0.03\left[\mathrm{~g} / \mathrm{m}^{3}\right]$ 程度の值で流下していることが分かる. 一方, 観測值は赤丸で示寸ような支流等の影響を受け, 計算値 のように值の推移が単調ではないということが分かる. この原因は本計算においては栄養塩等の横流入を適切に 考慮できていないためであると考えられる.

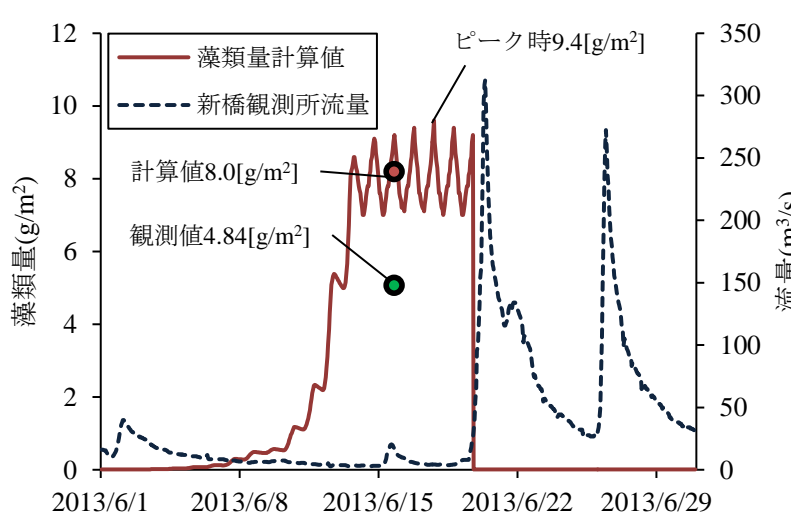

図-9＼cjkstart新橋地点における付着藻類量の観測値と 計算値の比較

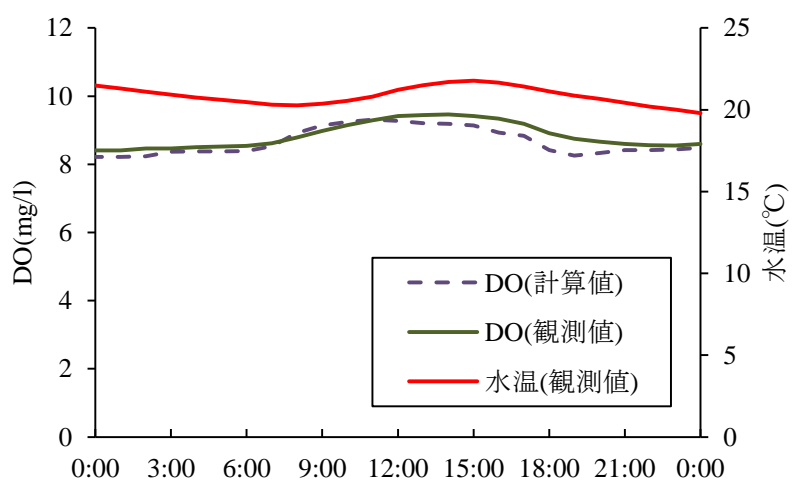

図-10＼cjkstart新橋地点における溶存酸素量の観測値と 計算値の比較

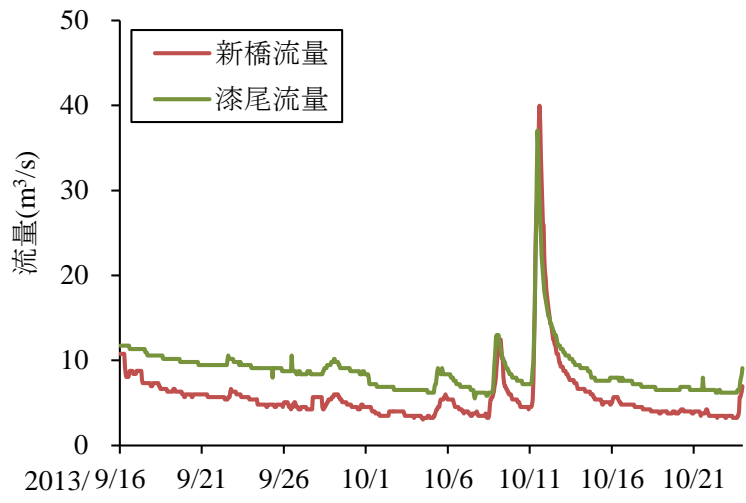

図-11＼cjkstart長期計算に用いた各観測所流量

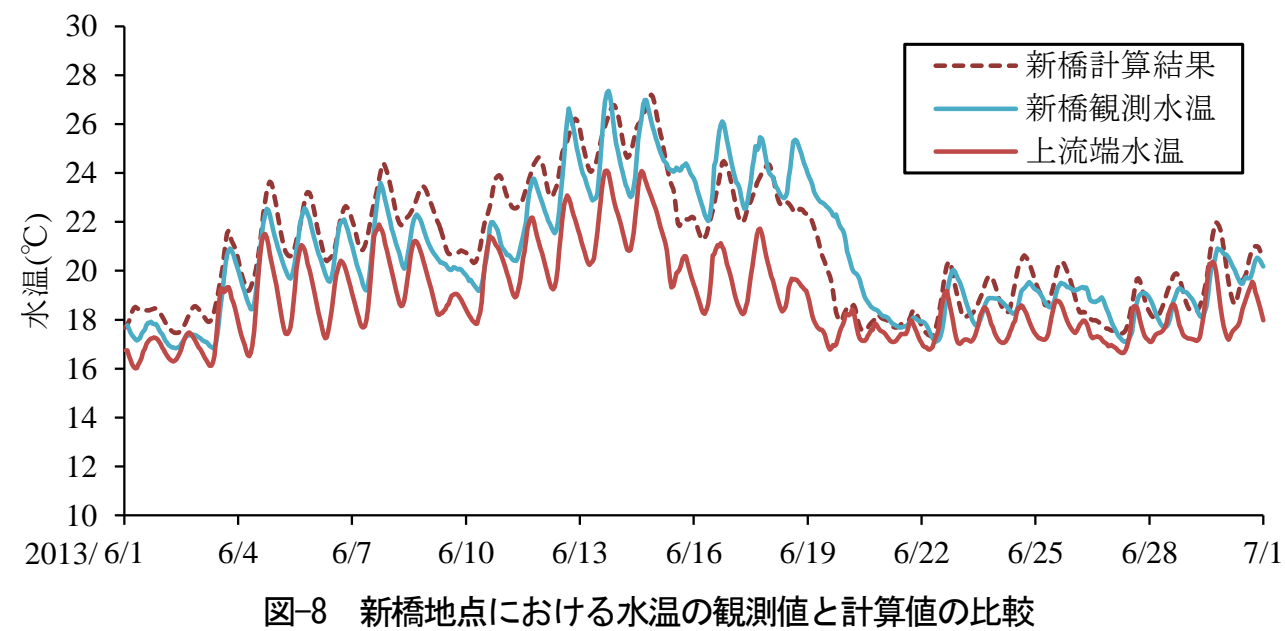




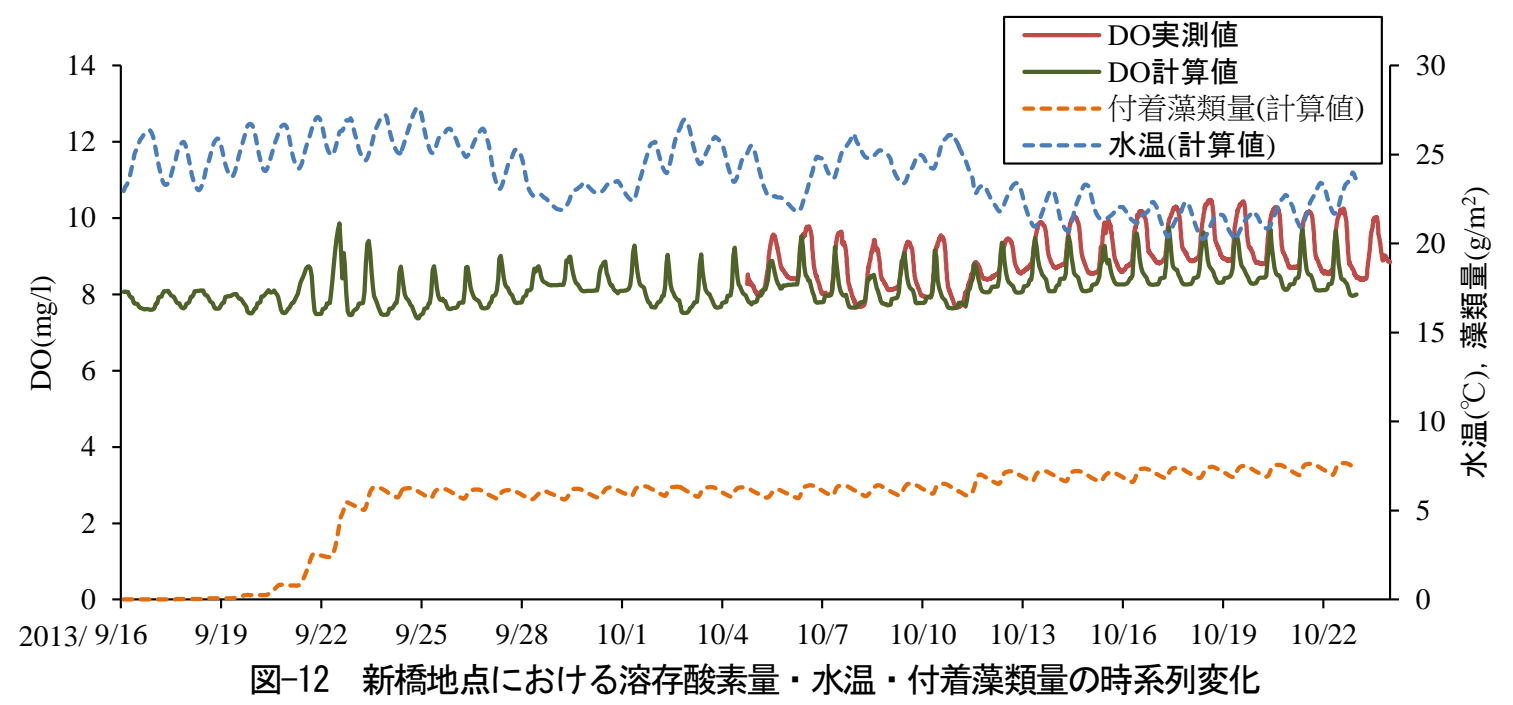

\section{4. 結論}

本研究は，河川の上流から下流まで一貫して取り扱う ことができる一次元生態系モデルの開発を行い，山口県 佐波川において本モデルを適用し，モデルの有用性を検 証した。 その結果，流れ場に関しては高い再現性を有す ることがわかった．また，水温や溶存酸素濃度に関して も実測で得られた流下による水温の変化や溶存酸素濃度 の日変動をよく再現することが明らかとなった．付着藻 類量については過大評価になることが分かった.さらに, 対象とした区間のリン酸態リン濃度の縦断分布について は再現性が低いことが分かった．これは，支流からの栄 養塩負荷を適切に考慮できていないためであると考えら れる.このような横流入を含めた流域からの負荷を適切 に取り入れることが今後の課題である.

謝辞 : 本研究は国土交通省受託研究「佐波川の河床掘 削・堰撤去が河川環境に与える影響の研究」（研究代表 者：赤松良久）の一環として行われている．記して謝意 を表す。

\section{参考文献}

1）楠田哲也，嚴佐庸/編:生態系とシミュレーション，朝倉書 店, 2002 .

2） 戸田祐嗣，池田駿介·砂床河川の物質循環シミュレーショ ン，土木学会論文集，No.635，pp.67-83， 2002.

3）赤松良久, 池田駿介：マングローブ水域における物質循環, 土木学会論文集，No.768/II -68,pp.193-208, 2004.

4） 溝口裕太，戸田祐嗣:粗粒有機物の供給・分解・輸送過程 を考慮した河川水系一貫物質循環解析，水工学論文集，第 55巻, pp.1333-1338, 2011.

5） 戸田祐嗣, 山下貴正, 宮本仁志, 辻本哲郎 : 数值河川生態

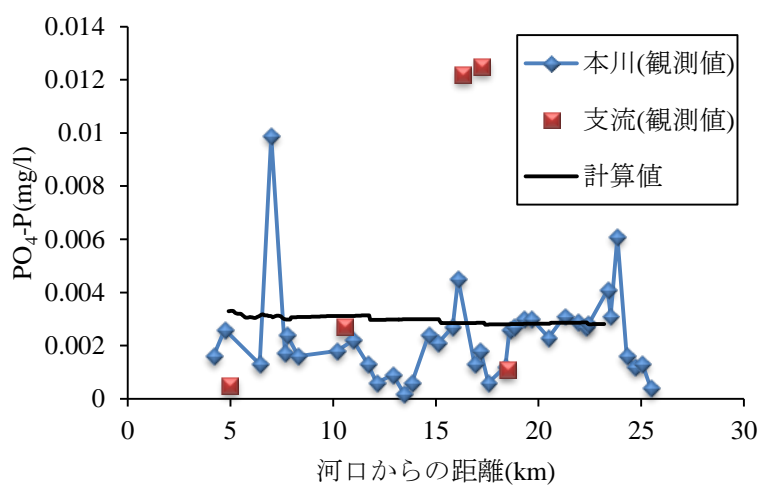

図-13 $\quad \mathrm{PO}_{4}-\mathrm{P}$ 縱断変化の観測値と計算値の比較

系の構築と流域河道網一の適用，土木学会論文集G（環 境），Vol.69, No. 6, II_127-II_138, 2013.

6) 近藤純正:河川水温の日変化(1)計算モデル-異常昇温と魚の 大量死事件-，水文・水資源学会誌，vol.8，No.2，pp.184196, 1995.

7）赤松良久, 池田駿介，浅野誠一郎，大澤和敏 : ダム下流 における糸状藻類の強制剥離に関する研究，土木学会論 文集 B，Vol.65，No.4，pp.285-295，2009.

8）今村正裕，本多正樹:アマモ場生態系モデルの開発とその 適用，土木学会論文集G，vol.62，No.2，pp.229-245，2006.

9）李寅鉄，関根雅彦，浮田正夫，中西弘：沿岸生態系モデル による瀬戸内海の水産資源量解析に関寸る研究，土木学会 論文集，No.566/VII-3，pp.81-93，1997.

10）芦田和男，道上正規：移動床ながれの抵抗と掃流砂に関 する基礎的研究，土木学会論文報告集，Vol.206，pp.59-69, 1972.

11) Itakura, T. and Kishi, T.: Open channel flow with suspended sediments, Proc.ASCE, Vol.106, No.HY8, pp.1325-1343, 1980.

(2014. 9. 30受付) 